\title{
Cardioprotective potency of anthocyanin-rich extract of red cabbage against isoproterenol-induced myocardial infarction in experimental animals
}

\author{
Doha Mohamed $^{1 *}$ (D), Hoda Mabrok ${ }^{1}$ (D), Sherein Abdelgayed ${ }^{2}$ (D), Hagar Elbakry ${ }^{1}$ \\ ${ }^{1}$ Nutrition and Food Sciences Department, National Research Centre, Cairo, Egypt. \\ ${ }^{2}$ Pathology Department, Faculty of Veterinary Medicine, Cairo University, Giza, Egypt.
}

\begin{tabular}{l}
\hline ARTICLE INFO \\
\hline Received on: 05/03/2021 \\
Accepted on: $15 / 05 / 2021$ \\
Available online: 05/08/2021 \\
\hline Key words: \\
Anthocyanin, red \\
cabbage, isoproterenol, \\
myocardial infarction, gene \\
expression, biochemical and \\
histopathological changes.
\end{tabular}

\section{INTRODUCTION}

Noncommunicable diseases are broad cluster diseases such as cardiovascular diseases (CVDs), cancer, diabetes, and respiratory diseases which are accountable for nearly $70 \%$ of all worldwide deaths (Iriti et al., 2020; Pati et al., 2019). In the 21st century, 17.3 million deaths from CVDs were recorded each year (Komal et al., 2021). All CVDs [heart failure, myocardial infarction (MI), and atherosclerosis] are accompanied by structural changes in the function of the cardiac tissue and blood vessels. In spite of global enhancements in health attendance, the death rate because of CVDs is progressively increased in medium- and low-

\section{${ }^{*}$ Corresponding Author}

Doha Mohamed, Nutrition and Food Sciences Department, National Research Centre, Cairo, Egypt.E-mail: dohamohamed @yahoo.com revenue countries (Kumar et al., 2016). MI accounts for $10 \%$ of the total death from CVDs (Arvanitis et al., 2020). Bad dietary habits, low activity, and lack of exercise are among the main causes of the spread of noncommunicable diseases, especially CVDs. So ingesting fresh foods that contain phytochemicals must be increased for health promotion. Edible plants contain a large amount of phytochemicals like phenolic compounds, polyphenols, and flavonoids. All these phytochemicals showed different biological activities like anticancer, anti-inflammatory, antioxidant, and glucose regulation (Mattioli et al., 2020). Anthocyanins are a class of polyphenols, which are pigments soluble in water present in flowers, fruits, and vegetables. Anthocyanins play an essential role in food palatability as they are responsible for its color (Ahmed et al., 2015). Anthocyanin dyes have been broadly used as natural food pigments. Also, these pigments are possibly useful as functional components, as they provide vital properties such as antioxidant, anticancer, and glucose regulation (He et al., 2010; 
Liu et al., 2018). Many coloring foods are the major source of anthocyanins like red cabbage, grapes, plums, and apples (Mattioli et al., 2020). Red cabbage (Brassica oleracea L.) is one of the richest sources of anthocyanins, especially acylated anthocyanins (Wiczkowski et al., 2013). Consumption of red cabbage possesses reduction of the incidence of chronic illnesses like cancer, CVDs, hyperlipidemia, and neurodegenerative diseases (Cruz et al., 2016; Mattioli et al., 2020; Tarozzi et al., 2013). It was reported previously that anthocyanins intake is associated with reduction of death from coronary heart disease (CHD) due to its antioxidant, anti-inflammatory, and dyslipidemic activities (Castaldo et al., 2019). Also, the authors decided that diet should contain food sources of anthocyanins to reduce the risk of CHD (Castaldo et al., 2019). The present research intended to estimate the cardioprotective of anthocyanin-rich extract of red cabbage (ARERC) in the MI model in rats. To realize this aim, antioxidant activity, total phenolic, and total anthocyanin of the extract were determined. Also, the acute toxicity of the extract was assessed.

\section{MATERIALS AND METHODS}

\section{Materials}

Red cabbages (B. oleracea L. var. capitata) were obtained from native markets, Giza, Egypt, and were stored at $4{ }^{\circ} \mathrm{C}$ until extraction.

\section{Animals}

Male Sprague-Dawley rats $140-180 \mathrm{~g}$ were used in the $\mathrm{MI}$ experiment. Animals were kept individually in stainless steel cages at room temperature of $25^{\circ} \mathrm{C} \pm 2{ }^{\circ} \mathrm{C}$ and relative humidity of about 55\%; water and food were given ad libitum. Adult normal male and female albino mice of 21-25 g body weight were used in acute oral toxicity. Animals were provided from animal house of the National Research Centre (NRC), Egypt. This study has been carried out as a part of internal project number 12050203 in the NRC. This project was permitted by the Medical Research Ethics Committee, NRC, with approval number 19176, and followed the recommendations of the National Institutes of Health Guide for Care and Use of Laboratory Animals (Publication No. 85-23, revised 1985).

\section{Animals' diet}

Corn oil (10\%), 12.5\% casein, $45.3 \%$ maize starch, $22.7 \%$ sucrose, $5 \%$ fiber, $3.5 \%$ salt mixture, and $1 \%$ vitamin mixture were mixed for preparation of balanced diet for rats feeding. Salt and vitamin mixtures were prepared according to AIN-93 (Reeves et al., 1993).

\section{METHODS}

\section{Preparation of ARERC}

Red cabbage was washed and cut. The extraction procedure was carried out using the solid-liquid extraction method. Ethanol/water/citric acid mixture (70:30:0.5 $v / v / w)$ was used for extraction. Red cabbages were macerated in the extraction solvent $(1: 3 w / v)$ for 1 hour in a shaker (SCILOGEX- SK-0330-Pro); the extract was then centrifuged at $3,000 \times \mathrm{g}$ for 15 minutes. The solvent was completely evaporated from the extract under reduced pressure at $40^{\circ} \mathrm{C}$. ARERC was kept in freezer until used.

\section{Determination of total phenolics content}

Phenolics content was estimated colorimetrically in ARERC using Folin-Ciocalteu reagent (Singleton et al., 1999). Absorbance was measured at $765 \mathrm{~nm}$ using UV visible spectrophotometer. The total phenolic content was expressed as gallic acid equivalents (GAE) in $\mathrm{mg} / \mathrm{g}$ extract. The results were expressed as mean $\pm \mathrm{SD}$.

\section{Determination of total anthocyanin}

Total anthocyanin as cyanidin-3-O-glucoside was measured according to the method of Sims and Gamon (2002). Total anthocyanin as cyanidin-3-O-glucoside $(\mathrm{mg} / \mathrm{l})=(\mathrm{Abs} \times$ M.W. $\times$ D.F. $\times 1,000) /(\varepsilon \times 1)$

Where is: MW (molecular weight of cyanidin-3-Oglucoside $)=449.2 \mathrm{~g} / \mathrm{mol}$

D.F. $=$ dilution factor, $1=$ path length in $\mathrm{cm}, \varepsilon$ (molar absorbance coefficient for cyanidin-3-O-glucoside $=26,900$ molar extinction coefficient, in $11 \times \mathrm{mol} / 1 \times \mathrm{cm}^{-1}$ ), 1,000 factor conversion from $\mathrm{g}$ to $\mathrm{mg}$ (Tonutare et al., 2014).

\section{Determination of antioxidant activity of ARERC}

The antioxidant activity of ARERC was determined using two models of antioxidant systems. The first one is (1,1-diphenyl-2-picrylhydrazyl) (DPPH)-free radical scavenging activity according to the method of Shekhar and Anju (2014) and the second is reducing capacity assessment according to the method of Yildirim et al. (2001). The percent of DPPH scavenging effect was calculated using the following equation:

DPPH scavenging effect $(\%)$ or Percent inhibition $=[\mathrm{A} 0$ $-\mathrm{A} 1 / \mathrm{A} 0] \times 100$, where A 0 was the absorbance of control reaction and $\mathrm{A} 1$ was the absorbance in presence of test or standard sample. Reducing capacity is calculated as follows:

$\mathrm{RP}=\left[\left(A_{\mathrm{m}} / A_{\mathrm{b}}-1\right) \times 100\right]$, where $A_{\mathrm{m}}$ was the absorbance of reaction mixture and $A_{\mathrm{b}}$ was the absorbance of blank mixture (Benkeblia, 2005).

\section{Acute oral lethal toxicity test of ARERC}

The acute toxicity of ARERC was evaluated using the method of Goodman et al. (1980). Normal male and female adult, albino mice of 21-25 g body weight were used. Mortality after 24 hours counts between mice groups ( 8 animals/group), which given progressively oral dosage levels of ARERC were recorded.

\section{Evaluation of cardioprotective effect of ARERC against isoproterenol-induced (ISO) MI}

Thirty-two male rats were allowed acclimatizing for 7 days in their cages before starting the experiment. Rats were divided into four groups (8/group) and fed on a balanced diet all over the experimental work (21 days). Group one was served as the normal control group, while group two was MI control. The third and fourth groups were given anthocyanin extracts orally on a daily basis at 100 and $200 \mathrm{mg} / \mathrm{kg}$ rat body weight, respectively. In the last 2 days (20th and 21st day) of the experiment, isoproterenol (Santa Cruz Biotechnology, Dallas, TX) solution in saline (85 mg/ $\mathrm{kg}$ ) was injected subcutaneously (Dianita et al., 2015) for all rats except the normal control group. Body weight was monitored once every week. At the end of the experiment, the final body weight of 
rats (FBW) was recorded. After overnight fasting, blood samples were collected from all rats in heparinized tubes. Plasma samples were separated for determination of total cholesterol (T-ch) (Allain et al., 1974), triglycerides (TG) (Fossati and Prencipe, 1982), and high-density lipoprotein cholesterol (HDL-Ch) (Burstein et al., 1970). Low-density lipoprotein cholesterol (LDL-Ch) was calculated [LDL-Ch=Tc-HDL-c-(TG/5)]. Oxidized-LDL (OxLDL) was determined using an ELISA kit (Catalogue \# SL0554Ra, Sunlong ${ }^{\mathbb{R}}$ ). Plasma malondialdehyde (MDA) was assessed as an indicator of lipid peroxidation (LPO) (Satoh, 1978). Plasma catalase activity (CAT) (Aebi, 1984) and superoxide dismutase (SOD) (ELISA kit, Catalogue \# SL1341Ra, Sunlong ${ }^{\circledR}$ ) were analyzed as an indicator of antioxidant status, while C-reactive protein (CRP) was determined as inflammatory marker using ELISA kit (Catalogue \# SL0202Ra Sunlong ${ }^{\circledR}$ ). Plasma activities of cardiac marker enzyme aminotransferase [alanine transaminase (ALT) and aspartate transaminase (AST)] (Reitman and Frankel, 1957), lactate dehydrogenase (LDH) (Van der Heiden et al., 1994), and creatine kinase (CK) (Hørder et al., 1990) were measured. Plasma creatinine (Bartles et al., 1972) and urea (Fawcett and Scott, 1960) were estimated as kidney function indicator. After animal anesthesia and scarification, the heart was dissected and weighed. Relative heart weight was calculated as follows: Relative heart weight $=$ Absolute heart weight $(\mathrm{g}) \times 100 / \mathrm{FBW}(\mathrm{g})$.

\section{Gene expression analysis of IL-6, IL-1 $\beta$, and 5HT-7}

PureLink ${ }^{\circledR}$ RNA Mini-kit (Ambion ${ }^{\circledR}$ Life-Technologies ${ }^{\mathrm{TM}}$ ) was used to isolate total RNA from heart tissue according to the manufacturer's directions. cDNA was synthesized from total RNA $(1.5 \mu \mathrm{g})$ with RevertAid first-strand cDNA synthesized-kit (ThermoFisher ${ }^{\mathbb{B}}$ Invitrogen ${ }^{\mathrm{TM}}$ ) according to the manufacturer's directions.

The reagent reaction mixture $(25 \mu \mathrm{l})$ consisted of $12.5 \mu \mathrm{l}$ of SYBR Green master mix (Thermo-Fisher ${ }^{\circledR}$ Invitrogen ${ }^{\mathrm{TM}}$ ), cDNA template $(1 \mu \mathrm{l})$, and primer pairs $(0.25 \mu \mathrm{M})$. The sequence of primer pairs was obtained from Khan et al. (2013) and Cinar et al. (2020) for interleukin-6 (IL-6), IL-1 $\beta$, and 5-hydroxytryptamine-7 receptor (5-HT7) (Table 1). Real-time PCR was performed with a Rotor-Gene ${ }^{\circledR} \mathrm{MDx}$ instrument programmed at 2 minutes at $50^{\circ} \mathrm{C}$ followed by 10 minutes at $95^{\circ} \mathrm{C}, 45$ cycles $\left(95^{\circ} \mathrm{C}\right.$ for 20 seconds, $60^{\circ} \mathrm{C}$ for 30 seconds, and $72^{\circ} \mathrm{C}$ for 30 seconds), melting curve program $\left(60^{\circ} \mathrm{C}-95^{\circ} \mathrm{C}\right)$. The negative control was PCR-water. The target gene's relative expressions were calculated according to Livak and Schmittgen (2001) method (delta-delta CT method); the target gene expression was normalized to glyceraldehyde-3phosphate dehydrogenase (housekeeping gene expression).

Table 1. Sequences of primer pairs for RT-PCR amplification.

\begin{tabular}{lc}
\hline Sequences & Target genes \\
\hline FW (5'-TGA TGG ATG CTT CCA AAC TG-3') & IL-6 \\
RW (5'-GAG CAT TGG AAG TTG GGG TA-3') & \\
FW (5'-CAC CTT CTT TTC CTT CAT CTT TG-3') & IL-1 $\beta$ \\
RW (5'-GTC GTT GCT TGT CTC TCC TTG TA-3') & \\
FW (5'-AGACTGCTCAAA CACGAAAGG-3') & 5HT-7 receptor \\
RW (5'-AAG GCT CCC ACG ATG ATC C-3') & \\
FW (5'-GTATTGGGCGCCTGGTCACC-3') & GAPDH \\
RW (5'-CGCTCCTGGAAGATGGTGATGG-3') &
\end{tabular}

\section{Histopathological examination}

For histopathological examination, heart was collected from all rats' groups and fixed in 10\% buffered formalin. Twentyfour hours later, heart tissues were washed three times in $70 \%$ ethanol, dried using a graded ethanol series, and then fixed in paraffin wax. Paraffin sections were cut into 5 - $\mu \mathrm{m}$ thick slices and stained with hematoxylin and eosin for light microscope examination. The sections were viewed and photographed using a digital microscope (Olympus BX50, Japan) (Bancroft et al., 2012).

\section{Statistical analysis}

Data were analyzed by one-way $\mathrm{C}$ analysis of variance followed by the Tukey multiple comparison test using software C Statistical Package for the Social Sciences 22. Differences were considered significant at $p \leq 0.05$. Data are expressed as mean \pm standard error (mean $\pm \mathrm{SE})$.

\section{RESULTS}

\section{Phenolic, anthocyanin content, and antioxidant activity of ARERC}

The total phenolics and total anthocyanin content of ARERC are shown in Figure 1. Total phenolic compounds were present by $639.2 \pm 2.57 \mathrm{mg}$ GAE/100 g extract, while total anthocyanin was present by $618.2 \pm 0.98 \mathrm{mg}$ Cy3G/100 g extract.

Figure 2 showed the results of the antioxidant activity of ARERC using two methods of antioxidant activities. The first one is free radical scavenger activity using DPPH as free radical, while the second is the reducing power method. In the two studied methods of antioxidants, the activity is increased in accordance with the increment of the concentration of the extract. In the case of DPPH (Fig. 2a), red cabbage showed the maximum inhibition percent at the level of $500 \mathrm{mg} / \mathrm{ml}(85 \%)$ and it is similar to that observed by BHT $(88.8 \%)$. In the reducing capacity method, red cabbage extract reduced $\mathrm{Fe}^{3+}$ from potassium ferrocyanide to $\mathrm{Fe}^{2+}$ which leads to the appearance of Prussian blue. This color increased with the concentration of the reducing power of ARERC (Fig. 2b).

\section{Effect of ARERC on plasma antioxidant status and inflammatory markers}

In the present study, MI was induced in rats through subcutaneous injection by ISO. In the present study, MDA as LPO indicator and CRP as inflammatory marker elevate significantly in the MI group (Table 2) in comparison with the normal group. Antioxidant enzymes CAT and SOD reduced significantly in the

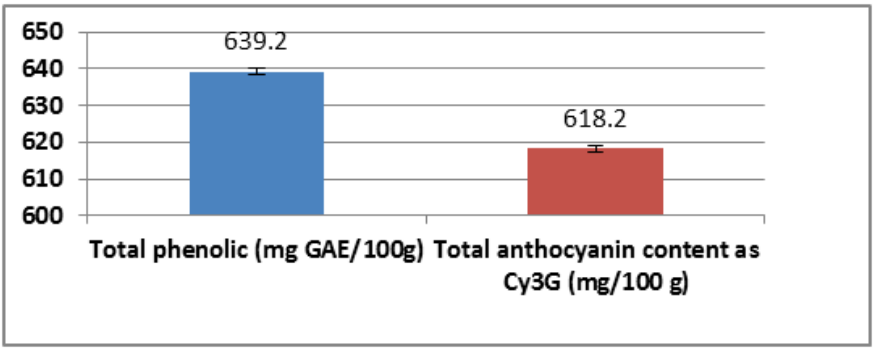

Figure 1. Total phenolic and anthocyanin contents of red cabbage extract. 
MI group in comparison with normal control. Oral administration of ARERC exhibited significant improvement in the antioxidant status (reduction of MDA and elevation of CAT and SOD) in association with a reduction in CRP as an inflammatory marker compared with MI control.

\section{Impact of ARERC on plasma lipid profile and Ox-LDL}

Plasma lipid profile and Ox-LDL of different experimental groups are present in Figure 3. Injection of rats with isoproterenol induces a significant increase of plasma TG, T-ch,

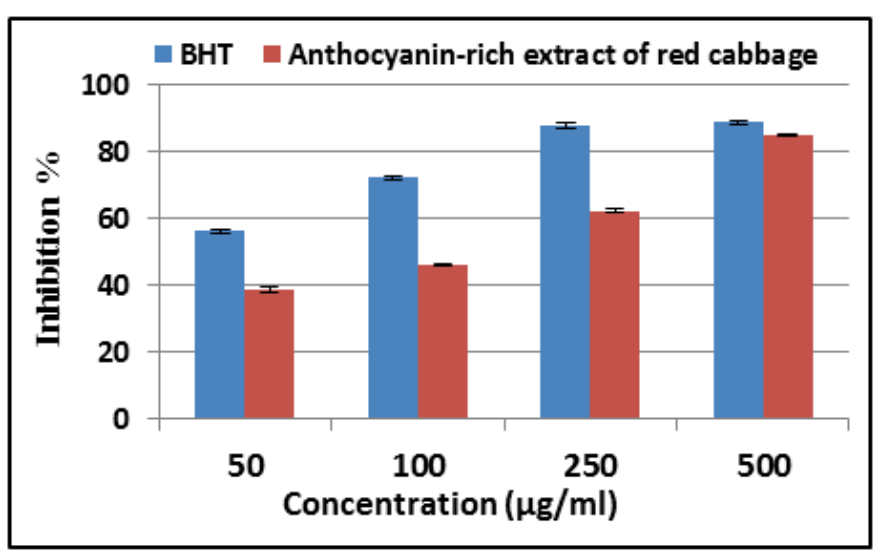

(a)

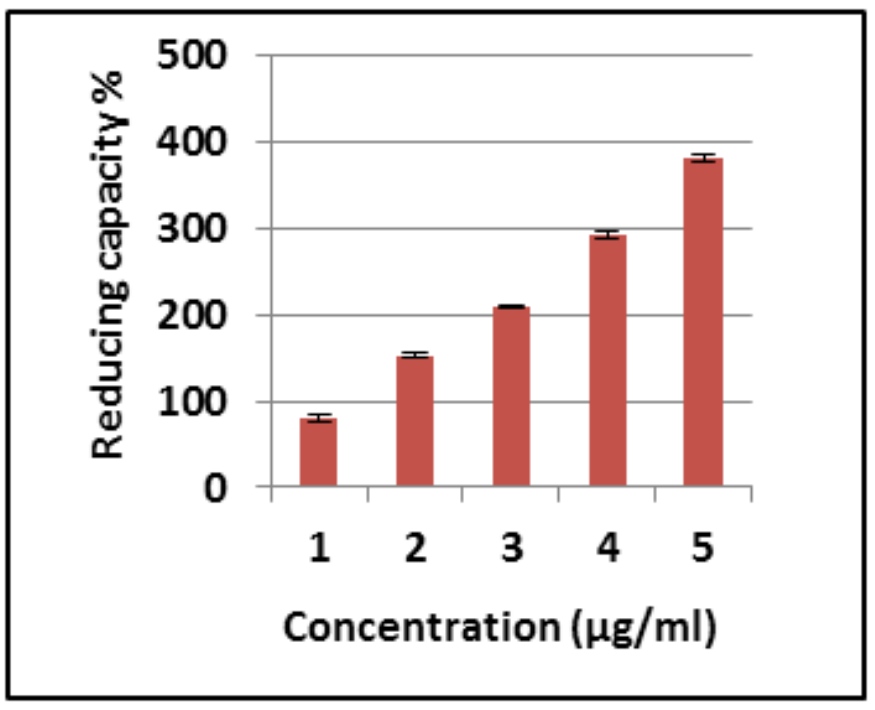

(b)

Figure 2. Antioxidant activity of ARERC (a) Free radical scavenger activity of BHT and ARERC. (b) Reducing capacity of ARERC.
LDL-Ch, and Ox-LDL in association with significant decline in HDL-Ch in the MI rat model in comparison with normal control. Administration of ARERC orally in low and high dose significantly attenuated the elevation of plasma T-ch, TG, LDLch, and Ox-LDL and improved the level of HDL-ch significantly compared with the MI group.

\section{Effects of ARERC on cardiac marker enzymes}

Table 3 presented a significant elevation in the levels of LDH, ALT, and AST in the MI rats. Oral dose of ARERC significantly decreased the elevation of those enzymes as compared to the MI group. In the present research, CK showed significant raise in the MI group compared with the normal group (Table 3). Kidney function parameters (creatinine and urea) increased significantly in the MI control group in comparison with normal control (Table 3). Oral administration of ARERC attenuates the elevation in kidney functions significantly compared with MI control. Also, CK levels reduced significantly in rat's groups given oral dose of ARERC compared with the MI group and similar to the normal group.

\section{Effect of MI and ARERC on body weight and relative heart weight}

Effect of ISO and ARERC on relative heart weight, FBW, and body weight gain appears in Figure $4 \mathrm{a}$ and $\mathrm{b}$. The relative heart weight of the MI group elevates significantly in comparison with normal control and rats given ARERC (Fig. 4a). FBW and body weight gain showed a nonsignificant difference between all groups.

\section{Effect of MI and ARERC on gene expression of IL-6 and IL- $1 \beta$ receptor}

The inflammatory cytokines IL-6 and IL-1 $\beta$ gene expression elevated significantly in MI control in comparison with normal control. 5-HT7 receptor mRNA expression was elevated

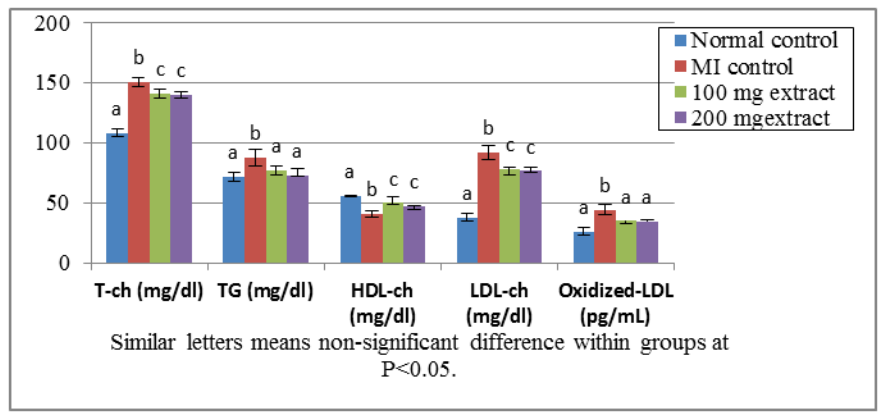

Figure 3. Plasma lipid profile and Ox-LDL of the different experimental groups.

Table 2. Effect of ARERC on plasma antioxidant status and inflammatory marker

\begin{tabular}{|c|c|c|c|c|}
\hline & $\operatorname{MDA}(\mathrm{mmol} / \mathrm{ml})$ & Catalase (U/I) & $\operatorname{SOD}(\mathrm{U} / \mathrm{ml})$ & $\mathrm{CRP}(\mathrm{ng} / \mathrm{ml})$ \\
\hline Normal control & $3.64^{\mathrm{a}} \pm 0.078$ & $436.45^{\mathrm{a}} \pm 8.23$ & $11.28^{\mathrm{b}} \pm 0.272$ & $2.87^{\mathrm{a}} \pm 0.098$ \\
\hline MI control & $5.70^{c} \pm 0.158$ & $356.00^{\mathrm{b}} \pm 08.44$ & $01.97^{\mathrm{a}} \pm 0.133$ & $8.24^{\mathrm{b}} \pm 0.188$ \\
\hline Low dose of anthocyanin-rich extract & $4.27^{\mathrm{b}} \pm 0.098$ & $380.25^{\mathrm{b}} \pm 09.01$ & $8.088^{\mathrm{d}} \pm 0.262$ & $6.30^{c} \pm 0.134$ \\
\hline High dose of anthocyanin-rich extract & $4.47^{\mathrm{b}} \pm 0.130$ & $381.25^{\mathrm{b}} \pm 07.42$ & $09.18^{\mathrm{c}} \pm 0.264$ & $5.05^{\mathrm{d}} \pm 0.217$ \\
\hline
\end{tabular}

means $=n \pm \mathrm{SE}$, where $n=8$.

In the same column, the similar letters mean nonsignificant difference within groups at $p \leq 0.05$. 
Table 3. Effects of anthocyanin-rich extracts of red cabbage on cardiac marker enzymes and kidney functions in rats.

\begin{tabular}{lcccccc}
\hline & LDH (U/l) & CK (U/l) & AST (IU/l) & ALT (IU/I) & Urea (mg/dl) & Creatinine (mg/dl) \\
\hline Normal control & $170.92^{\mathrm{a}} \pm 7.157$ & $50.88^{\mathrm{a}} \pm 2.805$ & $69.17^{\mathrm{a}} \pm 0.59$ & $07.40^{\mathrm{a}} \pm 0.204$ & $21.55^{\mathrm{a}} \pm 2.84$ & $0.74^{\mathrm{a}} \pm 0.037$ \\
MI control & $192.15^{\mathrm{b}} \pm 3.814$ & $70.49^{\mathrm{b}} \pm 4.797$ & $73.15^{\mathrm{b}} \pm 0.308$ & $09.65^{\mathrm{b}} \pm 0.509$ & $32.97^{\mathrm{b}} \pm 3.28$ & $0.85^{\mathrm{b}} \pm 0.027$ \\
Low dose of anthocyanin-rich extract & $176.58^{\mathrm{a}} \pm 1.238$ & $51.32^{\mathrm{a}} \pm 6.287$ & $67.10^{\mathrm{a}} \pm 0.876$ & $08.29^{\mathrm{a}} \pm 0.492$ & $23.54^{\mathrm{a}} \pm 1.74$ & $0.59^{\mathrm{c}} \pm 0.018$ \\
High dose of anthocyanin-rich extract & $179.39^{\mathrm{a}} \pm 7.797$ & $51.07^{\mathrm{a}} \pm 6.863$ & $68.85^{\mathrm{a}} \pm 1.490$ & $8.33^{\mathrm{a}} \pm 0.198$ & $24.57^{\mathrm{a}} \pm 1.09$ & $0.69^{\mathrm{a}} \pm 0.041$ \\
\hline
\end{tabular}

Means $=n \pm \mathrm{SE}$, where $n=8$.

In the same column, the similar letters mean nonsignificant difference within groups at $p \leq 0.05$.

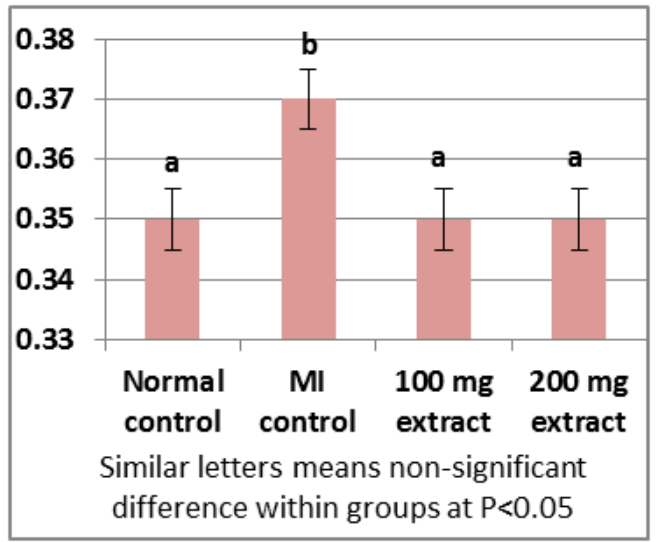

(a)

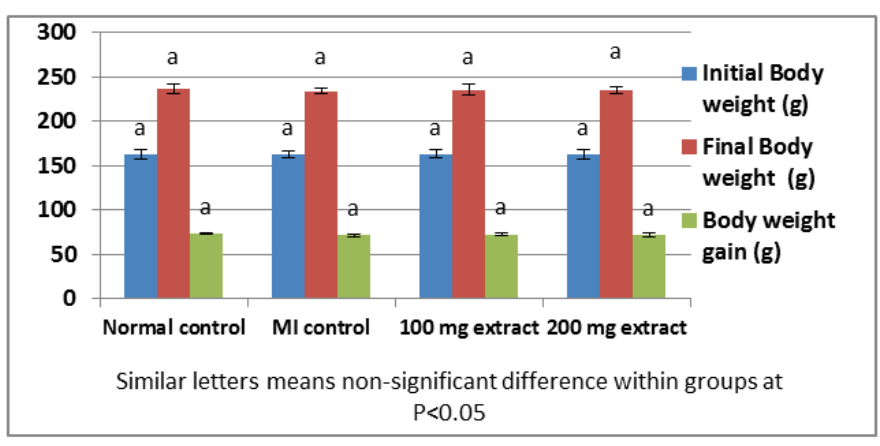

(b)

Figure 4. (a) Relative heart weight (\%) of different experimental groups. (b) Initial body weight, FBW, and body weight gain of different experimental groups.

significantly in the MI group in comparison with the normal group (Fig. 5). Low dose and high dose of ARERC significantly downregulated the gene expression of IL-6 by 2.4- and 4.7fold changes as compared to MI control and downregulated the expression of IL-1 $\beta$ by 3.9- and 4.5-fold change, receptively. 5HT7 receptor mRNA expression was significantly downregulated by treatments of low and high dose of ARERC.

\section{Histopathological examination of cardiac tissue}

Histopathological examination of cardiac tissue revealed that tissue of rat hearts from the normal group showed normal myocardial muscle (NM) with normal striation and nucleation (Fig. 6a). Diffuse areas of myocardial muscle hyalinosis and Zenker's necrosis, hemorrhage, and mononuclear cell infiltration were clearly visible by microscopy in heart of rats from the MI

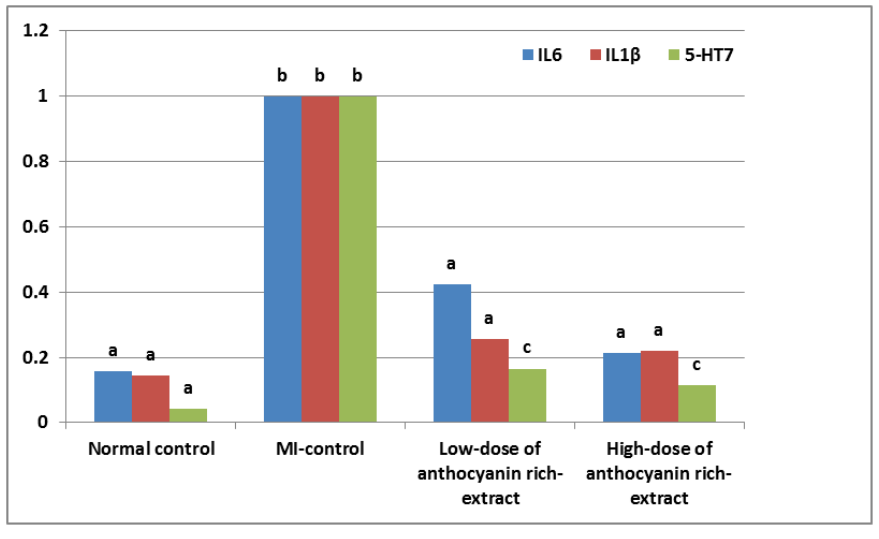

Figure 5. The relative expression of IL6, IL-1 $\beta$, and 5HT-7 receptor genes in heart of different experimental groups. The mRNA expression of IL6, IL-1 $\beta$, and 5HT-7 receptor is normalized with housekeeping gene (GAPDH); values are fold change of MI control and represent as means \pm SD. The same letter in each column is not significantly different and different letters are significantly different at the level of 0.05 probability levels.

control group (Fig. 6b and c). The MI group treated with a low dose of ARERC revealed apparently NM fibers together with regression of the mononuclear cell infiltration compared with the MI control group to a circumscribed focal area(Fig. 6d); also, there was congestion of the blood vessel as a sign of living muscle fibers (Fig. 6e) unlike the necrosed muscle fibers in the MI control group. The MI group treated with a high dose of ARERC showed NM with normal striation and nucleation highly resembling the control negative group (Fig. 6f).

\section{DISCUSSION}

Red cabbage ( $B$. oleracea L.) is one of the richest sources of anthocyanins (Wiczkowski et al., 2013). Consumption of red cabbage possesses a reduction in the incidence of chronic illnesses like cancer, hyperlipidemia, and neurodegenerative diseases (Cruz et al., 2016; Mattioli et al., 2020; Tarozzi et al., 2013). In the present study, ARERC contains a high level of total phenolic and total anthocyanin. It was reported previously that raw red cabbage contains total anthocyanins by $62.94 \mathrm{mg} / \mathrm{l}$ and total phenolic by $191.59 \mathrm{mg}$ GAE/100 g (Demírdöven et al., 2015). Jana et al. (2017) found that total anthocyanin content in red cabbage extract was $86.004 \mathrm{mg} / 100 \mathrm{~g}$ when extracted by methanol/water/formic acid. In the current research, ARERC possessed antioxidant activity in the DPPH and reducing capacity methods. In the two studied methods of antioxidants, the activity is increased in accordance with the increment of the concentration of the extract (Fig. 2a and b). The current results are in accordance 


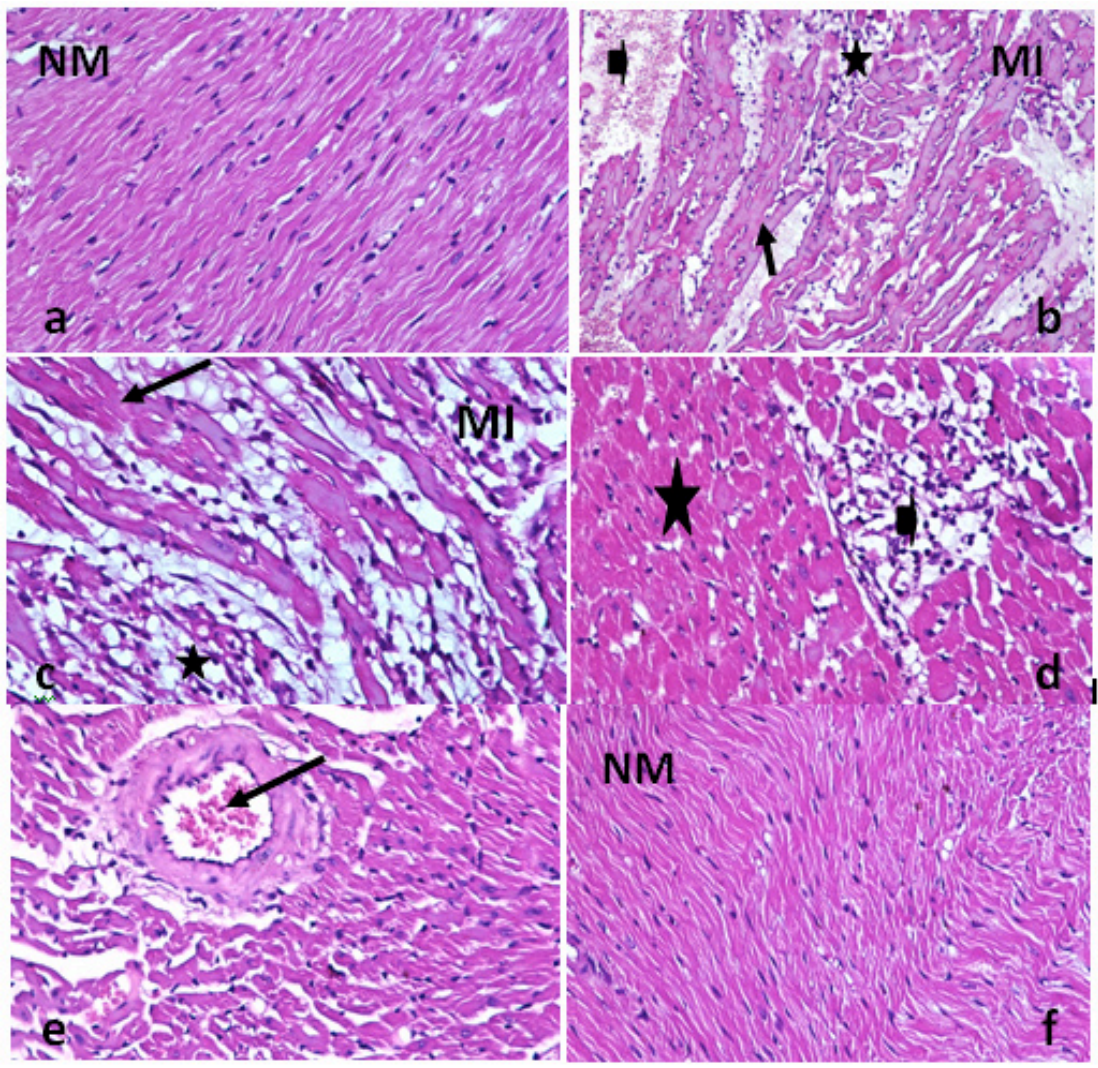

Figure 6. Micrographs of rats' heart from different groups showing the following: (a) Normal control group showing normal myocardial (NM) muscles; note the normal striation and nucleation (H\&E $\times 400)$. (b) MI group showing diffuse in the areas of myocardial muscle hyalinosis and Zenker's necrosis (arrow), hemorrhage (arrowhead), and mononuclear cell infiltration (*) (H\&E $\times 200)$. (c) MI group showing higher magnification of the myocardial muscle necrosis (H\&E $\times 400)$. (d) MI group treated with a low dose of ARERC showing NM muscles (*) and small focal area of mononuclear cell infiltration (arrowhead) (H\&E $\times 400)$. (e) MI group treated with a low dose of ARERC showing NM muscle and congested blood vessel (arrow) (H\&E $\times 400$ ). (f) MI group treated with a high dose of ARERC showing NM muscles $(\mathrm{NM})$; note the normal striation and nucleation $(\mathrm{H} \& \mathrm{E} \times 400)$.

with many previous studies which suggested that anthocyanins act as antiradical through quenching reactive radical species such as reactive oxygen/nitrogen species (Ali et al., 2016; Duchowicz et al., 2019; Nimse and Pal, 2015).

In the current research, MI was induced in rats through subcutaneous injection by ISO. This model is commonly used for the evaluation of the efficacy of new drugs or alternative treatments. ISO produces unrepairable damage in the cells and finally leads to necrosis of the myocardium (Shikalgar and Naikwade, 2018). ISO injection led to hypoxia ischemia through direct action on cardiac cardioprotective and vascular $\beta$-receptors, which finally induce necrosis of myocardium (Dianita et al., 2015). Induction of MI in rats is associated with the formation of reactive oxygen species (ROS) such as superoxide anion, hydrogen peroxides, and nitric oxide-derived peroxynitrite (Dianita et al., 2015). In the present study, the LPO marker, MDA, increased significantly in the MI group (Table 2). Elevation in MDA level may be attributed to an increment in ROS which leads to LPO. LPO is very harmful and responsible for organ and tissue damage (Zheng et al., 2017), which leads to inflammation and inflammatory markers as shown in the current research by the raise of CRP in plasma (Table 2) of the MI group. Results in Table 2 showed that there was an accelerating reduction of CAT levels, which seemed to be eminent to SOD in defending the cells from ROS-mediated damage which is similar to previous studies (Dianita et al., 2015; Raish et al., 2019). Administration of ARERC showed significant improvement in the antioxidant status (reduction of MDA and elevation of CAT and SOD) in association with a reduction in $\mathrm{CRP}$ as an inflammatory marker. The improvement in antioxidant status and inflammation in rats administered ARERC as revealed its cardioprotective efficacy against ROS release during the MI and this may be attributed to its activity as antioxidant as shown in the present study.

Injection of rats with ISO induces a significant rise in plasma TG, T-ch, LDL-Ch, and Ox-LDL in association with significant decline in HDL-Ch in the MI rat model. Improvement in dyslipidemia in the administration of ARERC orally in the current study is in accordance with the results of Raish et al. (2019). Consumption of red cabbage possesses a reduction in the incidence of CVDs and dyslipidemia (Cruz et al., 2016; Mattioli et al., 2020). Anthocyanin extract of purple sweet potato, black rice, and red Chinese cabbage reduces T-ch, non-HDL-ch, which leads to enhancement of atherosclerotic plaque stabilization (Joo et al., 2018; Miyazaki et al., 2008; Xia et al., 2006).

Table 3 showed a significant increase in the levels of LDH, AST, and ALT in the MI rats. LDH, AST, and ALT are enzymes used to diagnose the necrotic cells. ISO injection induced injury in the cardiomyocytes due to increment of ROS as 
observed in the present study (Table 2), which led to disruption in cell membranes and elevates enzymes levels in the blood (Khan et al., 2013). Pretreatment with ARERC decreased the elevation of these enzymes. ARERC significantly preserves the safety of the membrane cells, thus limiting the leak of those enzymes. This effect may be attributed to the antioxidant activity of the extract (Fig. 2). The necrosis of myocardial severity in experimental rats was reduced with an increase in oral dose of ARERC, which is in concert with previous studies (Dianita et al., 2015; Jana et al., 2017; Patel et al., 2012; Raish et al., 2019). In the present research, CK showed significant elevation in MI group (Table 3). CK is an important enzyme related to myocardium and relatively increased after myocardial injury. It elevates after 4-9 hours after infarction and returns to normal after 48-72 hours (Dianita et al., 2015). Kidney function parameters, creatinine and urea, were increased significantly in the MI group (Table 3). Oral administration of ARERC attenuates kidney function elevation. The present results are in concert with Ghartavol et al. (2019).

Relative heart weight of the MI group elevated in comparison with normal control and rats' groups given ARERC (Fig. 4a). The current findings are in agreement with the results observed by Shikalgar and Naikwade (2018) and Derbali et al. (2015). Elevation of relative heart weight of MI rats may be attributed to increment of water content and necrosis of myocardial muscle fibers followed by damage of tissue by inflammation of the cells (Rajadurai and Mainzen, 2007; Shikalgar and Naikwade, 2018).

The inflammatory cytokine IL-6 and IL-1 $\beta$ gene expression elevated significantly in the MI group. 5-HT7 receptor mRNA expression was raised significantly in the MI group (Fig. 5). The current findings are in covenant with the results observed by Cinar et al. (2020) who found that IL-6 mRNA expression and 5-HT7 receptor mRNA expression levels increased in MI control. Elevation in the mRNA expression of 5-HT7 receptor and inflammatory cytokines (IL-6 and IL-1 $\beta$ ) in the present research may be attributed to endothelial dysfunction due to damage of vascular tissues, through elevation of plasma TG, low-density lipoprotein, and Ox-LDL in the MI group as shown in Figure 3. It was reported previously that Ox-LDL increases 5-HT and stimulates thrombocyte aggregation (Zhao et al., 1995). Dyslipidemia in association with increment in LPO (MDA), reduction in antioxidant enzymes, and elevation of inflammatory maker C-reactive protein in MI control (Table 2) in the present study led to increasing serotonin (5-HT) release from thrombocytes, which induced thrombocyte aggregation in plasma. The increment in 5-HT increased vasoconstriction in association with increase 5-HT receptors such as 5-HT7 as observed in the present study. Low dose and high dose of ARERC significantly downregulated the gene expression of IL-6 by 2.4- and 4.7-fold changes as compared to MI control and downregulated the expression of IL-1 $\beta$ by 3.9- and 4.5fold change, receptively. 5HT-7 receptor mRNA expression was significantly downregulated by treatments of low and high dose of ARERC. Heart-specific gene regulation plays an important function in heart progress and age-related myocardial formation. Moreover, changes in gene expression in response to injury or stress participate in cardiac pathology (Komal et al., 2021). 5-HT plays an important role in mammal's heart such as increase heart rate, heart contraction, valve fibrosis, and thrombosis. 5-HT receptors (5-HT1 to 5-HT7) are responsible for all these effects. Serotonin modulated the release of IL-1 $\beta$ and IL- 6 through the activation of 5-HT4 and 5-HT7 receptors in LPS-stimulated human blood monocytes (Dürk et al., 2005). IL-1 $\beta$ and IL6 as inflammatory cytokines were shown to be upregulated in the myocardium early after injury (Deten et al., 2002; Frangogiannis et al., 1998; Kukielka et al., 1995). In the current study, 5-HT7, IL-1 $\beta$, and IL- 6 expression were elevated after MI and this elevation was reversed by the treatment of ARERC. It might be possible that ARERC improves cardiac remodeling through its anti-inflammatory effect in modulation of cytokines and stimulating serotonin receptors.

ISO injection leads to diffuse areas of myocardial muscle hyalinosis and Zenker's necrosis, hemorrhage, and mononuclear cell infiltration were clearly visible by microscopy in heart of rats from the MI control group (Fig. 6b and c). ARERC showed improvement in histopathology of the cardiac tissue, which may be attributed to its activity as antioxidant in vitro (Fig. 2) and in vivo (Table 2) due to the presence of phenolic compounds and anthocyanins and also may be attributed to its anti-inflammatory activity (Table 2) and lipid-lowering effect (Fig. 3) as revealed in the current research.

\section{CONCLUSION}

ARERC in the present study possesses a cardioprotective effect against ISO-induced MI. This effect is possibly resulting from its antioxidant and anti-inflammatory activities. The cardioprotective effect of ARERC is evidenced by reduction of inflammation, oxidative stress, dyslipidemia, and improvement of cardiac enzymes and also regulates gene expression of 5-HT7 receptors and inflammatory cytokines IL- 6 and IL- $1 \beta$ in association with reduction of relative heart weight. Finally, ARERC showed improvement in histopathology of the cardiac tissue.

\section{ACKNOWLEDGMENTS}

The authors acknowledge the NRC, Egypt, for funding this research through research project no. 12050203.

\section{AUTHOR CONTRIBUTIONS}

All authors made substantial contributions to conception and design, acquisition of data, or analysis and interpretation of data; took part in drafting the article or revising it critically for important intellectual content; agreed to submit to the current journal; gave final approval of the version to be published; and agree to be accountable for all aspects of the work. All the authors are eligible to be an author as per the international committee of medical journal editors (ICMJE) requirements/guidelines.

\section{CONFLICTS OF INTEREST}

The authors report no financial or any other conflicts of interest in this work.

\section{ETHICAL APPROVALS}

This project was permitted by the Medical Research Ethics Committee, NRC, with approval number 19176, and followed the recommendations of the National Institutes of Health Guide for Care and Use of Laboratory Animals (Publication No. 85-23, revised 1985). 


\section{PUBLISHER'S NOTE}

This journal remains neutral with regard to jurisdictional claims in published institutional affiliation.

\section{REFERENCES}

Aebi H. Catalase in vitro. Method Enzymol, 1984; 105:121-6; doi:10.1016/s0076-6879(84)05016-3

Ahmed NU, Park JI, Jung HJ, Hur Y, Nou IS. Anthocyanin biosynthesis for cold and freezing stress tolerance and desirable color in Brassica rapa. Funct. Integr. Genomics, 2015; 15(4):383-94; doi:10.1007/ s10142-014-0427-7

Ali HM, Almagribi W, Al-Rashidi MN. Antiradical and reductant activities of anthocyanidins and anthocyanins, structure-activity relationship and synthesis. Food Chem, 2016; 194:1275-82; doi: 10.1016/j. foodchem.2015.09.003

Allain CC, Poon LS, Chan CS, Richmond W, Fu PC. Enzymatic determination of total serum cholesterol. Clin Chem, 1974; 20(4):470-5.

Arvanitis M, Tampakakis E, Zhang Y, Wang W, Auton A, Dutta D, Glavaris S, Keramati A, Chatterjee N, Chi NC, Ren B, Post WS, Battle A. Genome-wide association and multi-omic analyses reveal ACTN2 as a gene linked to heart failure. Nat Commun, 2020; 11(1):1-12; doi: 10.1038/ s41467-020-14843-7

Bancroft JD, Suvarna K, Layton C. Bancroft's theory and practice of histological techniques. 7th edition, Churchill Livingstone, London, UK, p ix, 2012.

Bartles H, Bohmer M, Heierli C. Serum creatinine determination without protein precipitation. Clin Chim Acta, 1972; 37:193-7; doi: 10.1016/0009-8981(72)90432-9

Benkeblia N. Free-radical scavenging capacity and antioxidant properties of some selected onions (Allium cepa L.) and garlic (Allium sativum L.) extracts. Braz Arch Biol Technol, 2005; 48(5):753-9; doi:10.1590/S1516-89132005000600011

Burstein M, Scholnick HR, Morfin R. Rapid method for the isolation of lipoproteins from human serum by precipitation with polyanions. J Lipid Res, 1970; 11(6):583-95.

Castaldo L, Narváez A, Izzo L, Graziani G, Gaspari A, Minno G, Ritieni A. Red wine consumption and cardiovascular health. Molecules, 2019; 24(19):3626; doi:10.3390/molecules24193626

Cinar I, Halici Z, Dincer B, Sirin B, Cadirci E. The role of 5-HT7 receptors on isoproterenol-induced myocardial infarction in rats with highfat diet exacerbated coronary endothelial dysfunction. Hum Exp Toxicol, 2020; 39(8):1005-18; doi:10.1177/0960327120916821

Cruz AB, Pitz HS, Veber B, Bini LA, Maraschin M, Zeni AL. Assessment of bioactive metabolites and hypolipidemic effect of polyphenolic-rich red cabbage extract. Pharm Biol, 2016; 54(12):3033-9; doi: 10.1080/13880209.2016.1200633

Demírdöven A, Özdağan K, Erdoğan-Toktli K. Extraction of anthocyanins from red cabbage by ultrasonic and conventional methods: optimization and evaluation. J Food Biochem, 2015; 39(5):491-500; doi: $10.1111 /$ jfbc. 12153

Derbali A, Mnafgui K, Affes M, Derbali F, Hajji R, Gharsallah N, Allouche N, El Feki A. Cardioprotective effect of linseed oil against isoproterenol-induced myocardial infarction in Wistar rats: a biochemical and electrocardiographic study. J Physiol Biochem, 2015; 71(2):281-8; doi:10.1007/s13105-015-0411-2

Deten A, Volz HC, Zimmer HG. Cardiac cytokine expression is upregulated in the acute phase after myocardial infarction. Experimental studies in rats. Cardiovasc Res, 2002; 55(2):329-40; doi:10.1016/S00086363(02)00413-3

Dianita R, Jantan I, Amran AZ, Jalil J. Protective effects of Labisiapumilavar. Alataon biochemical and histopathological alterations of cardiac muscle cells in isoproterenol-induced myocardial infarction rats. Molecules, 2015; 20(3):4746-63; doi:10.3390/molecules20034746

Duchowicz PR, Szewczuk NA, Pomilio AB. QSAR studies of the antioxidant activity of anthocyanins. J Food Sci Technol, 2019; 56(12):5518-30; doi:10.1007/s13197-019-04024-w
Dürk T, Panther E, Müller T, Sorichter S, Ferrari D, Pizzirani C, Di Virgilio F, Myrtek D, Norgauer J, Idzko M. 5-Hydroxytryptamine modulates cytokine and chemokine production in LPS-primed human monocytes via stimulation of different 5-HTR subtypes. . Int Immunol, 2005; 17 (5): 599-606. ; doi:10.1093/intimm/dxh242

Fawcett JK, Scott JE. A rapid and precise method for the determination of urea. J Clin Pathol, 1960;13:156-9.

Fossati, P, Prencipe L. Serum triglycerides determined colorimetrically with an enzyme that produces hydrogen peroxide. Clin Chem, 1982;28(10):2077-80.

Frangogiannis NG, Youker KA, Rossen RD, Gwechenberger M, Lindsey MH, Mendoza LH, Michael LH, Ballantyne CM, Smith CW, Entman ML. Cytokines and the microcirculation in ischemia and reperfusion. J Mol Cell Cardiol, 1998; 30(12):2567-76; doi:10.1006/jmcc.1998.0829

Ghartavol MM, Aziz SG, Babaei G, Farjah GH, Ansari MHK The protective impact of betaine on the tissue structure and renal function in isoproterenol-induced myocardial infarction in rat. Mol Genet Genomic Med, 2019; 7(4):e00579; doi:10.1002/mgg3.579

Goodman AG, Goodman LS, Gilman A. Principles of toxicology. In: Goodman AG, Gilman A (eds.). The pharmacological basis of therapeutics, 6th edition, Macmillan, New York, NY, pp 1602-15, 1980.

He J, Giusti MM. Anthocyanins: natural colorants with healthpromoting properties. Annu Rev Food Sci Technol, 2010; 1:163-87; doi:10.1146/annurev.food.080708.100754

Hørder M, Elser RC, Gerhardt W, Mathieu M, Sampson EJ. International Federation of Clinical Chemistry (IFCC): Sscientific Ddivision, Ccommittee on Eenzymes. IFCC methods for the measurement of catalytic concentration of enzymes. Part 7. IFCC method for creatine kinase (ATP: creatine (N-phosphotransferase, EC 2.7. 3.2). IFCC Recommendation. . J Auto Chem, 1990; 12(1): 22--40;

Iriti M, Varoni EM, Vitalini S. Healthy diets and modifiable risk factors for non-communicable diseases-the European perspective. Foods, 2020; 9(7):940; doi:10.3390/foods9070940

Jana S, Patel D, Patel S, Upadhyay K, Thadani J, Mandal R, Das S, Devkar R. Anthocyanin rich extract of Brassica oleracea L. alleviates experimentally induced myocardial infarction. . PLoS One, 2017; 12(8): e0182137.

Joo H, Choi S, Lee Y, Lee E, Park M, Park K, Kim CS, Lim Y, Park JT, Jeon B Anthocyanin-rich extract from red Chinese cabbage alleviates vascular inflammation in endothelial cells and Apo E-/- mice. Int J Mol Sci, 2018; 19(3):816; doi:10.3390/ijms19030816

Khan HA, Alhomida AS, Sobki SH, Habib SS, Al Aseri, Khan AA, Al Moghairi A. Serum markers of tissue damage and antioxidative stress in patients with acute myocardial infarction. Biomed Res, 2013; 24(1):15-20. 25.

Komal S, Zhang L, Han S. Potential regulatory role of epigenetic RNA methylation in cardiovascular diseases. Biomed Pharmacother, 2021; 137:111376; doi:10.1016/j.biopha.2021.111376

Kukielka GL, Smith CW, Manning AM, Youker KA, Michael LH, Entman ML. Induction of interleukin-6 synthesis in the myocardium. Potential role in postreperfusion inflammatory injury. Circulation, 1995; 92:1866-75; doi:10.1161/01.cir.92.7.1866

Kumar M, Kasala ER, Bodduluru LN, Dahiya V, Sharma D, Kumar V, Lahkar M. Animal models of myocardial infarction: mainstay in clinical translation. Regul Toxicol Pharmacol, 2016; 76:221-30; doi:10.1016/j.yrtph.2016.03.005

Liu Y, Tikunov Y, Schouten RE, Marcelis LFM, Visser RGF, Bovy A. Anthocyanin biosynthesis and degradation mechanisms in Solanaceous vegetables: a review. Front Chem, 2018; 6:52; doi:10.3389/ fchem.2018.00052

Livak KJ, Schmittgen TD. Analysis of relative gene expression data using real-time quantitative PCR and the $2-\Delta \Delta \mathrm{Ct}$ method. Methods, $2001 ; 25: 402-8$.

Mattioli R, Francioso A, Mosca L, Silva P. Anthocyanins: a comprehensive review of their chemical properties and health effects on cardiovascular and neurodegenerative diseases. Molecules, 2020; 25(17):3809; doi:10.3390/molecules25173809 
Miyazaki K, Makino K, Iwadate E, Deguchi Y, Ishikawa F. Anthocyanins from purple sweet potato ipomoea batatas cultivar ayamurasaki suppress the development of atherosclerotic lesions and both enhancements of oxidative stress and soluble vascular cell adhesion molecule-1 in apolipoprotein E-deficient Mice. J Agric Food Chem, 2008; 56(23):11485-92; doi:10.1021/jf801876n

Nimse SB, Pal D. Free radicals, natural antioxidants, and their reaction mechanisms. RSC Adv, 2015; 5:27986-8006; doi:10.3390/ molecules25173809

Patel DK, Desai SN, Gandhi HP, Devkar RV, Ramachandran AV. Cardio-protective effect of Coriandrum sativum $\mathrm{L}$. on isoproterenol induced myocardial necrosis in rats. Food Chem Toxicol, 2012; 50(9):3120-5; doi:10.1016/j.fct.2012.06.033

Pati S, Sinha R, Mahapatra P. Non-communicable disease risk reduction teaching in India: a curricular landscape. Front Public Health, 2019; 7:133; doi:10.3389/fpubh.2019.00133

Raish M, Ahmad A, Ansari MA, Alkharfy KM, Ahad A, Khan A, Ali N, Ganaie MA, Hamidaddin MAA. Beetroot juice alleviates isoproterenol-induced myocardial damage by reducing oxidative stress, inflammation, and apoptosis in rats. Biotech, 2019; 9(4):147; doi:10.1007/ s13205-019-1677-9

Rajadurai M, Mainzen PS. Preventive effect of naringin on isoproterenol-induced cardiotoxicity in Wistar rats: an in vivo and in vitro study. Toxicol, 2007; 232(3):216-25; doi:10.1016/j.tox.2007.01.006

Reeves PG, Nielsen FH, Fahey GC. AIN-93 purified diets for laboratory rodents: final report of the American institute of nutrition Ad hoc writing committee on the reformulation of the AIN-76A rodent diet. J Nutr, 1993; 123:1939-51; doi:10.1093/jn/123.11.1939

Reitman S, Frankel S. Colorimetric methods for aspartate and alanine aminotransferase. Am J Clin Pathol, 1957; 28:55-60.

Satoh K. Serum lipid peroxide in cerebrovascular disorders determined by a new colorimetric method. Clin Chim Acta, 1978; 20:37-43.

Shekhar TC, Anju G. Antioxidant activity by DPPH radical scavenging method of Ageratum conyzoides Linn. Leaves. Am J Ethnomed, 2014; 1(4):244-9.

Shikalgar TS, Naikwade NS. Evaluation of cardioprotective activity of fulvic acid against isoproterenol induced oxidative damage in rat cardium. Int Res J Pharm, 2018; 9(1):71-80; doi:10.7897/2230-8407.09111

Sims DA, Gamon JA. Relationships between leaf pigment content and spectral reflectance across a wide range of species, leaf structures and developmental stages. Remote Sens Environ, 2002; 81:337-54.
Singleton VL, Orthofer R, Lamuela-Ravento's RM. Analysis of total phenols and other oxidation substrates and antioxidants by means of Folin-Ciocalteu reagent. Method Enzymol, 1999; 299:152-78; doi:10.1016/ S0076-6879(99)99017-1

Tarozzi A, Angeloni C, Malaguti M, Morroni F, Hrelia S, Hrelia P. Sulforaphane as a potential protective phytochemical against neurodegenerative diseases. Oxid Med Cell Longev, 2013; 2013:415078; doi:10.1155/2013/415078

Tonutare T, Moor U, Szajdak L. Strawberry anthocyanin determination by $\mathrm{pH}$ differential spectroscopic method - how to get true results? Acta Sci Pol Hortorum Cultus, 2014; 13(3):35-47.

Van der Heiden C, Bais R, Gerhardt W, Lorentz K, Rosalki $\mathrm{S}$. Approved recommendation on IFCC methods for the measurement of catalytic concentration of enzymes. Part 8. IFCC method for lactate dehydrogenase. . Eur J Clin Chem Clin Biochem; , 1994; ; 32 (8): 639-6-55.

Wiczkowski W, Szawara-Nowak D, Topolska J. Red cabbage anthocyanins: profile, isolation, identification, and antioxidant activity Food Res Int, 2013; 51(1):303-9.

Xia X, Ling W, Ma J, Xia M, Hou M, Wang Q, Zhu H, Tang Z. An anthocyanin rich extract from black rice enhances atherosclerotic plaque stabilization in apolipoprotein E deficient mice. J Nutr, 2006; 136(8):22205; doi:10.1093/jn/136.8.2220

Yildirim A, Mavi A, Kara AA. Determination of antioxidant and antimicrobial activities of Rumex crispus L. extracts. J Agri Food Chem, 2001; 49(8):4083-9; doi:10.1021/jf0103572

Zhao B, Dierichs R, Harrach-Ruprecht B, Winterhorff $\mathrm{H}$. Oxidized LDL induces serotonin release from blood-platelets. Am J Hematol, 1995; 48(4):285-28; doi:10.1002/ajh.2830480417

Zheng S, Sun C, Chen J. Cardioprotective effect of indirubin in experimentally induced myocardial infarction in wistar rats. Int J Clin Exp Pathol, 2017; 10(7):8082-90.

How to cite this article:

Mohamed D, Mabrok H, Abdelgayed S, Elbakry H. Cardioprotective potency of anthocyanin-rich extract of red cabbage against isoproterenol-induced myocardial infarction in experimental animals. J Appl Pharm Sci, 2021; 11(08):022-030. 